\title{
Iron-Catalyzed Methylation Using the Borrowing Hydrogen Approach
}

\author{
Kurt Polidano, ${ }^{\dagger}$ Benjamin D. W. Allen, ${ }^{\dagger}$ Jonathan M. J. Williams, $^{\dagger}$ and Louis C. Morrill ${ }^{*}{ }^{\dagger}$ \\ ${ }^{\dagger}$ School of Chemistry, Cardiff University, Main Building, Park Place, Cardiff, CF10 3AT, U.K. \\ ${ }^{\ddagger}$ Department of Chemistry, University of Bath, Claverton Down, Bath, BA2 7AY, U.K.
}

\section{Supporting Information}
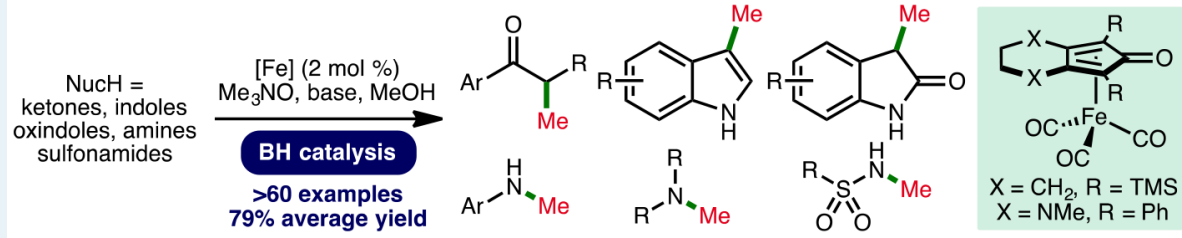

ABSTRACT: A general iron-catalyzed methylation has been developed using methanol as a C1 building block. This borrowing hydrogen approach employs a Knölker-type (cyclopentadienone)iron carbonyl complex as catalyst (2 mol \%) and exhibits a broad reaction scope. A variety of ketones, indoles, oxindoles, amines, and sulfonamides undergo mono- or dimethylation in excellent isolated yields (>60 examples, $79 \%$ average yield).

KEYWORDS: borrowing hydrogen, iron catalysis, methylation, methanol, mechanistic studies

M ethylation is a fundamental transformation in synthetic chemistry that is widely used for the synthesis and functionalization of fine chemicals. ${ }^{1}$ Traditional methylation procedures often employ toxic and/or potentially explosive reagents including iodomethane, dimethyl sulfate, or diazomethane, among many others. ${ }^{2}$ In recent years, methanol, an abundant and biodegradable liquid, has emerged as an attractive alternative reagent for methylation. ${ }^{3}$ Borrowing hydrogen $(\mathrm{BH})$, or hydrogen autotransfer, combines a transfer hydrogenation process with a concurrent reaction on the in situ-generated reactive intermediate. ${ }^{4}$ This one-pot oxidationreaction-reduction sequence has received much attention due to its inherent high atom economy and minimal waste generation, ${ }^{5}$ allowing bench stable and inexpensive alcohols to be used as alkylating agents. ${ }^{6}$ In comparison with benzyl and long-chain $n$-alkyl alcohols, it is challenging to use methanol as the alkylating agent in $\mathrm{BH}$ processes, due partly to the increased energy of dehydrogenation $(\Delta H(\mathrm{MeOH})=+84 \mathrm{~kJ}$ $\mathrm{mol}^{-1}$, cf. $\left.\Delta H(\mathrm{EtOH})=+68 \mathrm{~kJ} \mathrm{~mol}^{-1}\right)^{7}$ to form the required transient reactive formaldehyde intermediate.

Following the pioneering work of Grigg on the rutheniumand rhodium-catalyzed methylation of arylacetonitriles and aromatic amines, ${ }^{8}$ respectively, there have been a number of subsequent reports describing precious metal-catalyzed $\mathrm{BH}$ methylation (Scheme 1A). ${ }^{9}$ Despite these advances, a key challenge in hydrogen transfer chemistry is the development and use of catalysts based on earth-abundant, inexpensive metals for more sustainable processes. ${ }^{10}$ Considerable progress has been made in this regard, with well-defined iron, manganese, and cobalt catalysts being employed for a variety of homogeneous $\mathrm{BH}$ alkylation processes. ${ }^{11}$ With the vast majority of reports primarily focusing on the use of benzyl
Scheme 1. Previous Work and Outline of the Fe-Catalyzed BH Methylation Strategy

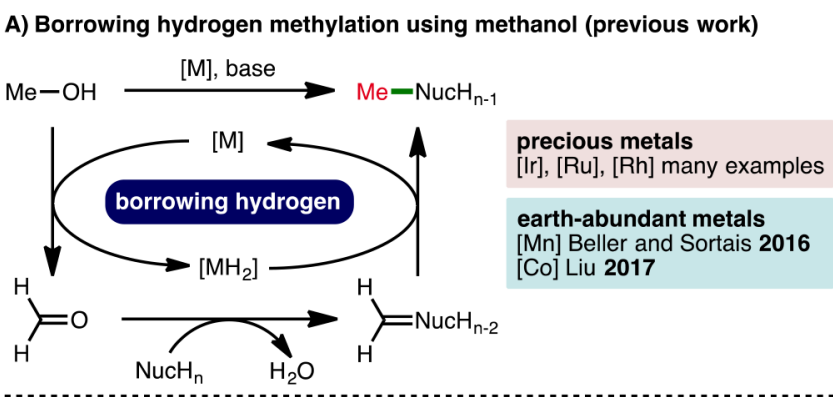

B) Fe-catalyzed BH methylation of diverse pronucleophiles (this work)
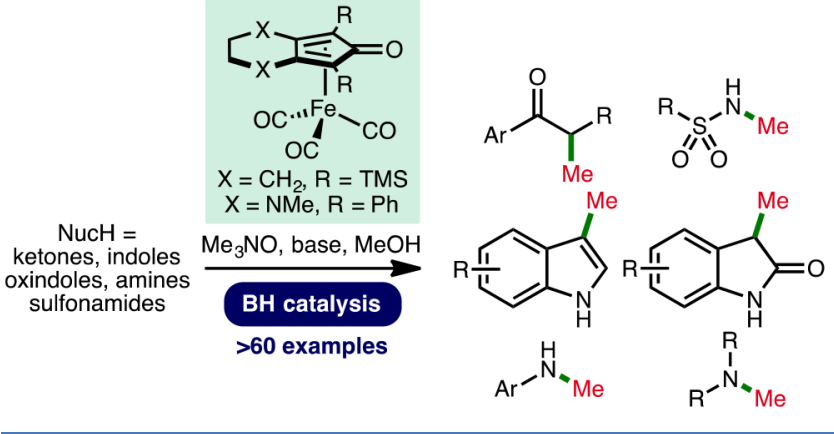

alcohols as alkylating agents, Beller and Sortais have reported the methylation of aromatic amines using manganese pincer

Received: June 4, 2018

Revised: June 11, 2018

Published: June 14, 2018 
complexes. ${ }^{12}$ Furthermore, Liu has recently disclosed a cobaltbased catalytic system for methylation. ${ }^{13}$ However, the catalytic $\mathrm{BH}$ methylation using iron, ${ }^{14}$ the most abundant transition metal in the Earth's crust, remains an unsolved problem. Herein, we report an efficient and general ironcatalyzed methylation of ketones, indoles, oxindoles, amines, and sulfonamides using methanol as a sustainable $\mathrm{C} 1$ building block (Scheme 1B).

To commence our studies, we selected butyrophenone $\mathbf{1}$ as a model substrate (Table 1). After extensive optimization, ${ }^{15}$ it

Table 1. Optimization of Fe-Catalyzed BH Methylation ${ }^{a}$

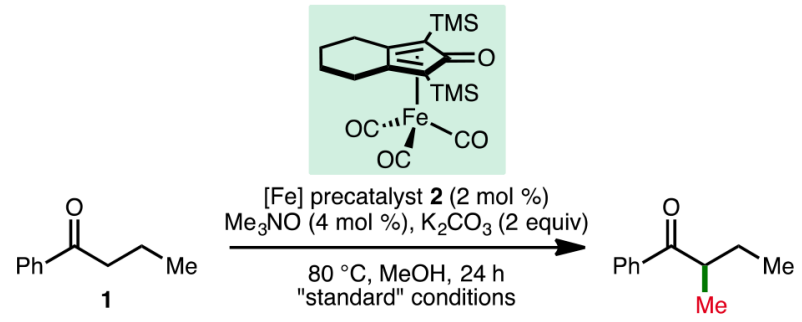

$$
\begin{aligned}
& 3 \\
& \begin{array}{clc}
\text { entry } & \text { variation from "standard" conditions } & \text { yield }^{b}(\%) \\
1 & \text { none } & >98(88)
\end{array} \\
& 2 \text { no }[\mathrm{Fe}] \text { precatalyst }<2 \\
& 3 \text { no } \mathrm{Me}_{3} \mathrm{NO} \text { activator } 55 \\
& 4 \mathrm{PPh}_{3}(4 \mathrm{~mol} \%) \text { instead of } \mathrm{Me}_{3} \mathrm{NO} \quad 37 \\
& 5 \quad 2 \mathrm{~mol} \% \text { of } \mathrm{Me}_{3} \mathrm{NO} \quad 92 \\
& 6 \mathrm{KOH} \text { (2 equiv) instead of } \mathrm{K}_{2} \mathrm{CO}_{3} \quad 93 \\
& 7 \quad \mathrm{KOt} \text {-Bu (2 equiv) instead of } \mathrm{K}_{2} \mathrm{CO}_{3} \quad 91 \\
& 8 \quad \mathrm{~K}_{2} \mathrm{CO}_{3} \text { (0.5 equiv) } 85 \\
& 9 \quad \mathrm{MeOH} \text { :toluene (1:1) } 40 \\
& 10 \quad[1]=0.2 \mathrm{M} \quad 94 \\
& 11 \quad[1]=1 \mathrm{M} \\
& 12 \quad 100{ }^{\circ} \mathrm{C} \quad 94 \\
& 13 \quad 60^{\circ} \mathrm{C} \quad 88 \\
& 14^{c} \quad[\mathrm{Fe}] \text { precatalyst } 2(1 \mathrm{~mol} \%) \quad 81
\end{aligned}
$$

${ }^{a}$ Reactions performed using $1 \mathrm{mmol}$ of ketone 1 and bench-grade $\mathrm{MeOH}$. $[1]=0.5 \mathrm{M}$. ${ }^{b}$ Yield after $24 \mathrm{~h}$ as determined by ${ }^{1} \mathrm{H}$ NMR analysis of the crude reaction mixture with 1,3,5-trimethylbenzene as the internal standard. Isolated yield given in parentheses. ${ }^{c} 2 \mathrm{~mol} \%$ of $\mathrm{Me}_{3} \mathrm{NO}$.

was found that a $\mathrm{BH}$ system composed of Knölker-type (cyclopentadienone)iron carbonyl precatalyst $2(2 \mathrm{~mol} \%){ }^{16}$ trimethylamine $\mathrm{N}$-oxide (4 mol \%) to activate the catalyst, ${ }^{17}$ $\mathrm{K}_{2} \mathrm{CO}_{3}$ (2 equiv) as base in $\mathrm{MeOH}([\mathbf{1}]=0.5 \mathrm{M})$ at $80^{\circ} \mathrm{C}$ for $24 \mathrm{~h}$, enabled the methylation of 1 , giving 3 in $98 \%$ NMR yield and $88 \%$ isolated yield (entry 1 ). No methylation occurs in the absence of the iron precatalyst 2 (entry 2 ), with a significant reduction in conversion observed in the absence of trimethylamine $\mathrm{N}$-oxide (entry 3). Substituting $\mathrm{Me}_{3} \mathrm{NO}$ for $\mathrm{PPh}_{3}$ as activator or lowering the loading of $\mathrm{Me}_{3} \mathrm{NO}$ to $2 \mathrm{~mol} \%$, both result in decreased NMR yield of 3 (entries 4 and 5). Employing $\mathrm{KOH}$ or $\mathrm{KOt}$-Bu as base, or using substoichiometric quantities of $\mathrm{K}_{2} \mathrm{CO}_{3}$ ( 0.5 equiv) all result in lower conversions to 3 (entries 6-8). Using methanol as solvent is crucial, with a mixed solvent system $(\mathrm{MeOH}$ :toluene $(1: 1))$ resulting in only 40\% NMR yield (entry 9). Altering the reaction concentration (entries 10 and 11), reaction temperature (entries 12 and 13), or reducing the catalyst loading to 1 mol \% (entry 14), lowers the efficiency of the methylation of 1 to 3 .
The full scope of the Fe-catalyzed $\mathrm{BH}$ methylation process was explored, starting with the mono- and dimethylation of ketones (Scheme 2A). ${ }^{18}$ Using the optimized reaction conditions (Table 1, entry 1 ) a variety of aryl alkyl substituted ketones were converted to the corresponding methylated products in excellent isolated yields (products 3-21, 87\% average yield). Acetophenone derivatives bearing $\alpha$-alkyl (Me, Et, $n$-Pr, $n$-Bu, Bn), $\alpha$-phenyl and $\alpha$-heteroatom (OMe, OPh, $\mathrm{NHPh}$ ) substitution undergo efficient methylation without cleavage of the carbon-heteroatom bonds within products 911. ${ }^{19}$ Within the aryl unit, $4-\mathrm{CF}_{3}, 3-\mathrm{CF}_{3}$, and $2-\mathrm{CF}_{3}$ substitution is tolerated in addition to halide $(4-\mathrm{Cl})$ and electron-donating (4-OMe) substituents. Hindered extended aromatic systems (1-Np) and heteroaryls (2-furanyl, 2thiophenyl and 3-pyridyl) can also be present within the ketone. The monomethylation procedure performs well upon scale-up, with the formation of $\mathbf{3}$ successfully carried out on a $10 \mathrm{mmol}$ scale in 99\% (1.61 g) isolated yield. 5-, 6-, and 7membered cyclic ketones also undergo methylation, using $\mathrm{KO}$ - $\mathrm{Bu}(10 \mathrm{~mol} \%)$ as base, giving products 22-24. A representative selection of acetophenone derivatives, which are unsubstituted at the $\alpha$-position, undergo dimethylation using 2 equiv of $\mathrm{KO} t$-Bu at $110^{\circ} \mathrm{C}$ in high isolated yields (products 4, 13, 16, 17, and 25-27, $74 \%$ average yield). The catalytic system tolerated the reducible benzyl ether moiety within $\mathbf{2 6}$. Selectivity considerations exist when employing ketones that are enolizable at both $\alpha$-positions. Phenyl acetone, 1phenylbutan-2-one, and dibenzyl ketone undergo selective monomethylation at $80{ }^{\circ} \mathrm{C}$, giving 28,29 , and 30 in $50 \%, 58 \%$, and $57 \%$ isolated yields, respectively. For phenyl acetone and 1-phenylbutan-2-one, monomethylation occurs preferentially at the more acidic benzylic position.

Next, we explored the use of indoles and oxindoles as substrates for the $\mathrm{Fe}$-catalyzed $\mathrm{BH}$ methylation process (Scheme $2 \mathrm{~B} / \mathrm{C}$ ). Using 2 equiv of $\mathrm{K}_{2} \mathrm{CO}_{3}$ as base, a variety of indoles undergo $\mathrm{C}(3)$-methylation in high isolated yields (products $31-36,78 \%$ average yield). ${ }^{20}$ In addition to unsubstituted indole, methyl and halide substituents are tolerated at the 2-, 4-, 5-, 6-, and 7-positions. Furthermore, by employing $\mathrm{CD}_{3} \mathrm{OD}$ as solvent, $d_{3}$-skatole 37 , which has utility in studying metabolism kinetics, ${ }^{21}$ was accessed in $67 \%$ yield. Oxindoles, a class of activated amide, also undergo facile $C$ (3)-methylation at $110{ }^{\circ} \mathrm{C}$ (products $38-44,77 \%$ average yield). $N$-Methyl, $N$-benzyl, and $N$-phenyl substitution is tolerated in addition to various halide substitutions at the 5position. This is the first example of borrowing hydrogen $C$ methylation of an amide using a homogeneous catalytic system. $^{22}$

We also investigated the Fe-catalyzed $\mathrm{BH} \mathrm{N}$-methylation of amines using methanol (Scheme 2D). Using the optimized reaction conditions (Table 1 , entry 1 ), a variety of arylamines undergo monomethylation in high isolated yields (products 45-50, 74\% average yield). Within the aryl unit, electrondonating (4-OMe) substituents are tolerated in addition to halides (4-Br, 4-Cl), hindered aromatic systems (2-Me), and heteroaryls (3-pyridyl). ${ }^{23} \mathrm{~A}$ selection of cyclic and acyclic secondary amines also undergo efficient $\mathrm{N}$-monomethylation, accessing the corresponding tertiary amines in high yields (products 51-55, 78\% average yield). Finally, employing Renaud's (cyclopentadienone)iron carbonyl precatalyst 61 (4 mol \%), ${ }^{24}$ which contains a more electron-rich cyclopentadienone framework, the $\mathrm{N}$-monomethylation of sulfonamides was also demonstrated (products 56-59, 83\% average 
Scheme 2. Scope of the Fe-Catalyzed BH Methylation Process ${ }^{\S}$
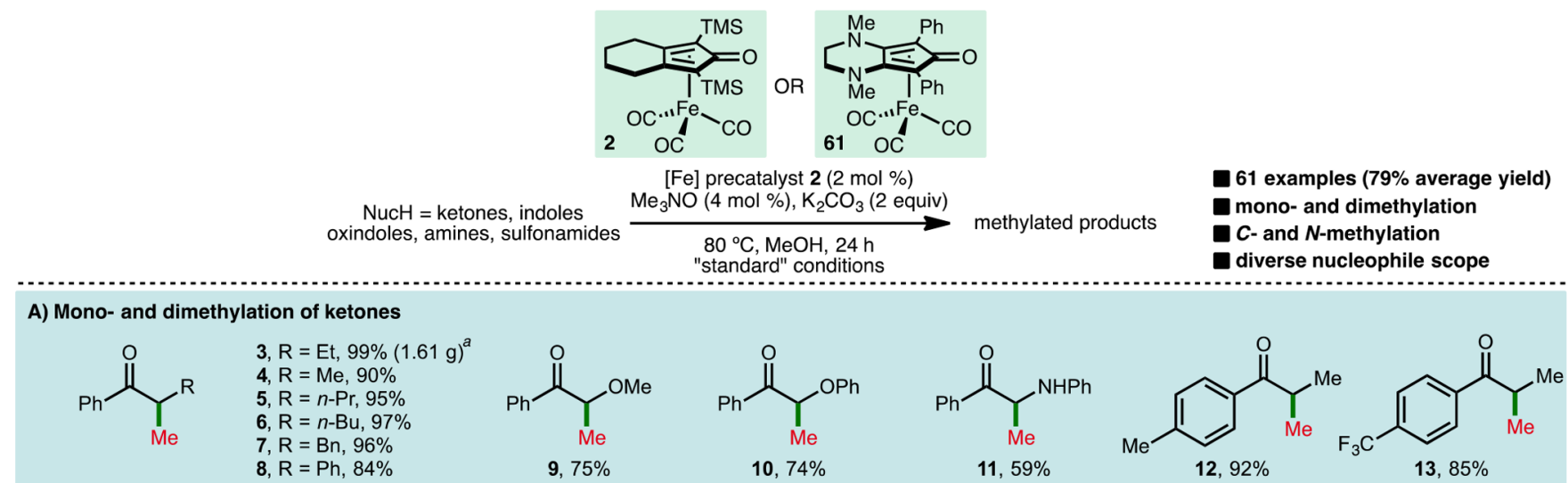

Me

$14,86 \%$<smiles>CC(C)C(=O)c1ccccc1C(F)(F)F</smiles>

$15,90 \%$<smiles>CC(C)C(=O)c1cccnc1</smiles><smiles>O=C1c2ccccc2CC1[N+](=O)[O-]</smiles>

$22,66 \%^{b}$<smiles>[CH2]C([18OH])C(=O)c1ccccc1</smiles>

9, $75 \%$<smiles>CC(C(=O)c1ccccc1)c1ccccc1</smiles>

$10,74 \%$<smiles>[Y9]C(N[P+](=O)c1ccccc1)C(=O)c1ccccc1</smiles>

$11,59 \%$<smiles>Cc1ccc(C(=O)C(C)C)cc1</smiles>

$12,92 \%$<smiles>CC(C)C(=O)c1ccc(C(F)(F)F)cc1</smiles>

$13,85 \%$<smiles>COc1ccc(C(=O)[C@H](N)C(=O)N[C@H](C)C(=O)c2ccc(Cl)cc2)c2ccccc12</smiles>

$16,91 \%$<smiles>CC(C)C(=O)c1ccco1</smiles>

19, $78 \%$<smiles>CC(C)C(=O)c1cccs1</smiles>

20, $85 \%$<smiles>CC1CCc2ccccc2C1=O</smiles>

23, $54 \%^{b, c}$<smiles>O=C1CCCc2ccccc21</smiles>

24, $94 \%$,<smiles>CC(N)C(=O)O</smiles>

$4,85 \%^{d}$<smiles>CC(C)C(=O)c1ccc(C(F)(F)F)cc1</smiles>

$13,57 \%^{d}$<smiles>CC(C)C(=O)c1ccc(Cl)cc1</smiles>

$16,68 \%^{d}$<smiles>COc1ccc(C(=O)C(C)C)cc1</smiles>

$17,86 \%$ d<smiles>Cc1ccccc1C(=O)C(C)C</smiles>
$\mathrm{BnO}^{-}$<smiles>CC(C)C(=O)c1ccc(I)cc1</smiles><smiles>[N]C(=O)C(=O)c1ccccn1</smiles><smiles>[NH3+]C(=O)C([NH3+])c1ccccc1</smiles><smiles>CC(=O)C([NH3+])c1ccccc1</smiles>

$29,58 \% b$<smiles>[N]C(C(=O)Cc1ccccc1)c1ccccc1</smiles>

$30,57 \%^{b}$

B) $C$-monomethylation of indoles<smiles>N#Cc1c[nH]c2ccccc12</smiles>

$31,82 \%$<smiles>Cc1[nH]c2ccccc2c1C</smiles>

32, $85 \%$

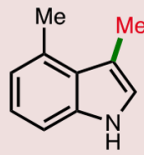

33, $66 \%$ e<smiles>Nc1c[nH]c2ccc(F)cc12</smiles>

$34,79 \%$<smiles>N#[W]c1c[nH]c2cc(Cl)ccc12</smiles>

35, $73 \%^{\theta}$

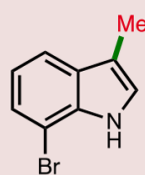

$36,82 \%$<smiles>Clc1c[nH]c2ccccc12</smiles>

$37,67 \%,>95 \% D^{c, f, g}$

C) C-monomethylation of oxindoles<smiles></smiles>

$38,86 \%^{c}$<smiles>Nc1ccccc1-n1c(=O)[nH]c2ccccc21</smiles>

39, $74 \%{ }^{c}$<smiles>NC1C(=O)Nc2ccccc21</smiles>

40, $86 \%$ c<smiles>CC1C(=O)Nc2ccccc21</smiles>

$41,58 \%$ c<smiles>NC1=Cc2ccc(Cl)cc2C1=O</smiles>

42, $85 \% c$<smiles>NC1C(=O)Nc2ccc(Br)cc21</smiles>

43, $71 \%^{\mathrm{C}}$<smiles>Nc1ccc2c(c1)C(=O)C(=O)N2</smiles>

$44,76 \%^{c}$

D) $\mathbf{N}$-monomethylation of amines and sulfonamides<smiles>CNc1ccccc1</smiles>

52, $76 \% c, g$<smiles>COc1ccc(NN(C)C)cc1</smiles><smiles>CNc1ccc(Br)cc1</smiles><smiles>[X]Nc1ccc(Cl)cc1</smiles>

$48,73 \%$<smiles>CN1CCc2ccccc2C1</smiles>

$53,84 \%^{c}$
$47,84 \%$<smiles>CN(C)Cc1ccccc1</smiles>

$54,78 \%{ }^{c}$

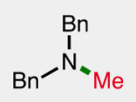

55, $74 \% c, 9$<smiles>O=[N+]([O-])c1ccccc1NS(=O)(=O)c1ccccc1</smiles><smiles>[N]Nc1cccnc1</smiles>

$49,54 \%{ }^{c, h}$<smiles>CS(=O)(=O)N[Na]</smiles>

56, $65 \% c$,

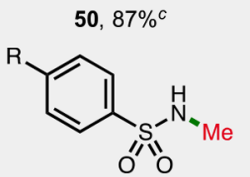

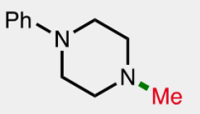

51, $77 \%$ c,g

57, $\mathrm{R}=\mathrm{H}, 79 \% c, i$

58, $\mathrm{R}=\mathrm{Me}, 92 \% \mathrm{c}, i$
59, $\mathrm{R}=\mathrm{OMe}, 95 \% c, i$

$59, \mathrm{R}=\mathrm{OMe}, 95 \% \mathrm{c}, i$
$\mathbf{6 0}, \mathrm{R}=\mathrm{CF}_{3},<2 \% \mathrm{c}, i$

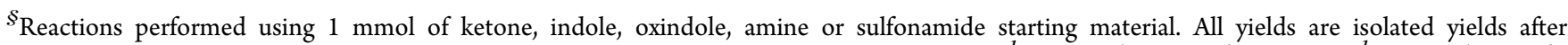
chromatographic purification Reagents and conditions: ${ }^{a} 10 \mathrm{mmol}$ of ketone starting material; ${ }^{b} \mathrm{KO} t$ - $\mathrm{Bu}(10 \mathrm{~mol} \%) ;{ }^{c} 110{ }^{\circ} \mathrm{C} ;{ }^{d} \mathrm{KO} t$-Bu $(2$ equiv); ${ }^{e} 48 \mathrm{~h} ;{ }^{f} \mathrm{CD}_{3} \mathrm{OD}$ as solvent; ${ }^{g}[\mathrm{Fe}]$ precatalyst 2 (4 mol \%), $\mathrm{Me}_{3} \mathrm{NO}(8 \mathrm{~mol} \%) ;{ }^{h} 96 \mathrm{~h} ;{ }^{i}[\mathrm{Fe}]$ precatalyst 61 (4 mol \%), $\mathrm{Me} 3 \mathrm{NO}(8 \mathrm{~mol} \%)$.

yield). Methanesulfonamide and sulfonamides containing electron-rich aromatic rings all undergo efficient $\mathrm{N}$-methylation, whereas $4-\mathrm{CF}_{3} \mathrm{C}_{6} \mathrm{H}_{4}$ substituted sulfonamide 60 was unreactive.

Selecting the monomethylation of propiophenone as a representative reaction, a number of experiments were performed in order to obtain mechanistic insight (Scheme $3)$. First, the validity of several proposed intermediates $(\beta$ hydroxy ketone 62, methyl ether 63, diketone 64, and enone 65) was probed by subjecting them to the "standard" methylation reaction conditions (Scheme 3A). Conjugate addition of methanol or the enolate of propiophenone to 
Scheme 3. Mechanistic Considerations

A) Validation of possible reaction intermediates

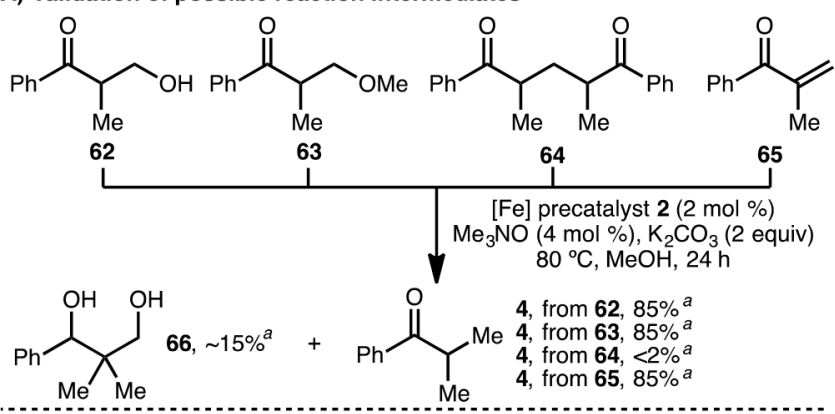

B) Evidence for iron hydride species and methanol as methylating agent

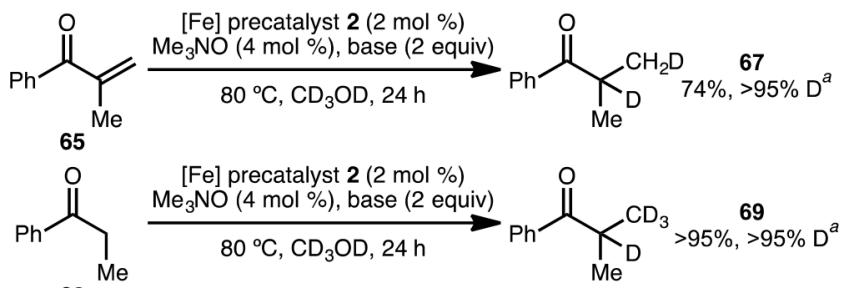

68

C) Plausible mechanism [Fe] precatalyst 2

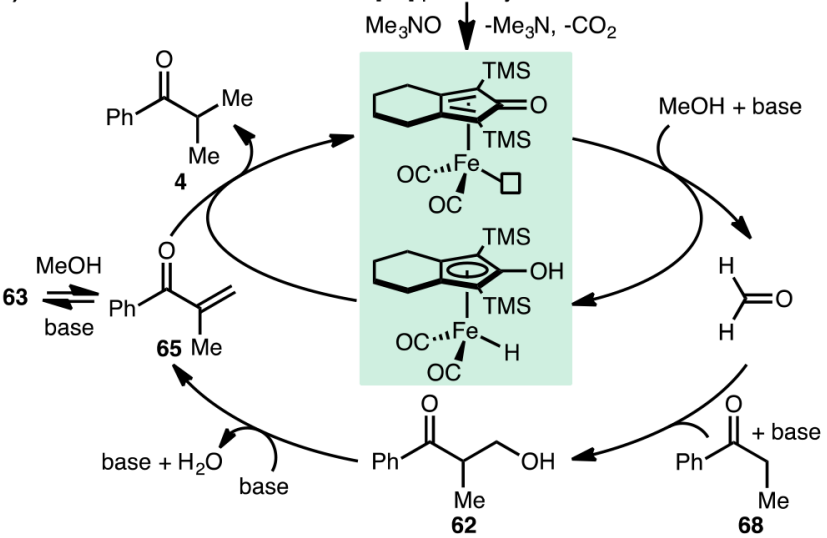

${ }^{a}$ Yield after $24 \mathrm{~h}$ as determined by ${ }^{1} \mathrm{H}$ NMR analysis of the crude reaction mixture with 1,3,5-trimethylbenzene as the internal standard.

enone 65, would result in the formation of 63 and 64, respectively. Compounds 62, 63, and $\mathbf{6 5}$ were all converted to 4 in $85 \%$ NMR yield, indicating that they are all plausible reaction intermediates. The remaining mass balance in these reactions $(\sim 15 \%)$ was diol 66 , which likely forms via conjugate addition of the iron hydride species to 65 , followed by trapping of the resulting enolate with formaldehyde and subsequent hydrogenation. $^{25}$ Diketone 64 was returned after $24 \mathrm{~h}$, indicating that this is a nonproductive reaction pathway and that 64 does not lead to the formation of 4 . To gain further mechanistic insight, employing $\mathrm{CD}_{3} \mathrm{OD}$ as solvent under the otherwise standard reaction conditions, enone 65 was converted to $67(74 \%,>95 \% \mathrm{D})$ providing evidence for the proposed iron hydride species (Scheme 3B). Furthermore, propiophenone 68 was converted to $69(>95 \%,>95 \% \mathrm{D})$, confirming that methanol is the source of the methyl group. As such, the proposed mechanism begins with $\mathrm{CO}$ decoordination by $\mathrm{Me}_{3} \mathrm{NO}$ to form the active iron complex, which abstracts hydrogen from methanol in the presence of base to form the required transient reactive formaldehyde intermediate (Scheme 3C). A subsequent aldol reaction with propiophenone generates $\beta$-hydroxy ketone $\mathbf{6 2}$ that undergoes basecatalyzed dehydration to form enone 65 , which may exist in equilibrium with 63 . Finally, reduction of enone 65 by the iron-hydrogen complex gives methylated product 4 with regeneration of the active iron complex.

In conclusion, we have developed a general and efficient Fecatalyzed methylation using methanol as a sustainable $\mathrm{C} 1$ building block via the borrowing hydrogen approach. A diverse array of ketones, indoles, oxindoles, amines, and sulfonamides undergo mono- or dimethylation in excellent isolated yields (61 examples, $79 \%$ average yield). Mechanistic experiments provided evidence for plausible reaction intermediates, an ironhydride species, and methanol as themethylating agent in this catalytic process. Ongoing studies are focused on further applications of earth-abundant transition metals in catalysis, and these results will be reported in due course.

\section{ASSOCIATED CONTENT}

\section{S Supporting Information}

The Supporting Information is available free of charge on the ACS Publications website at DOI: 10.1021/acscatal.8b02158.

Optimization data, experimental procedures, characterization of new compounds, and spectral data (PDF)

\section{AUTHOR INFORMATION}

\section{Corresponding Author}

*E-mail: MorrillLC@cardiff.ac.uk.

ORCID

Louis C. Morrill: 0000-0002-6453-7531

Notes

The authors declare no competing financial interest.

Information about the data that underpins the results presented in this article, including how to access them, can be found in the Cardiff University data catalogue at http://doi. org/10.17035/d.2018.0051041048 (accessed June 14, 2018)

\section{ACKNOWLEDGMENTS}

We gratefully acknowledge the School of Chemistry, Cardiff University for generous support, the EPSRC-funded Bath/ Bristol/Cardiff Catalysis Centre for Doctoral Training (K.P., EP/L016443/1), the EPSRC for a standard research grant (B.D.W.A., EP/R006504/1) and the EPSRC UK National Mass Spectrometry Facility at Swansea University.

\section{REFERENCES}

(1) (a) Barreiro, E. J.; Kümmerle, A. E.; Fraga, C. A. M. The Methylation Effect in Medicinal Chemistry. Chem. Rev. 2011, 111, 5215-5246. (b) Schönherr, H.; Cernak, T. Profound Methyl Effects in Drug Discovery and a Call for New C-H Methylation Reactions. Angew. Chem., Int. Ed. 2013, 52, 12256-12267.

(2) (a) Lamoureaux, G.; Agüero, C. A comparison of several modern alkylating agents. Arkivoc 2009, 251-264. (b) Szekely, G.; Amores de Sousa, M. C.; Gil, M.; Castelo Ferreira, F.; Heggie, W. Genotoxic Impurities in Pharmaceutical Manufacturing: Sources, Regulations, and Mitigation. Chem. Rev. 2015, 115, 8182-8229.

(3) (a) Olah, G. A. Towards Oil Independence Through Renewable Methanol Chemistry. Angew. Chem., Int. Ed. 2013, 52, 104-107. (b) Sam, B.; Breit, B.; Krische, M. J. Paraformaldehyde and Methanol as $\mathrm{C} 1$ Feedstocks in Metal-Catalyzed C-C Couplings of $\pi$ Unsaturated Reactants: Beyond Hydroformylation. Angew. Chem., Int. Ed. 2015, 54, 3267-3274. (c) Natte, K.; Neumann, H.; Beller, M.; Jagadeesh, R. V. Transition-Metal-Catalyzed Utilization of Methanol as a C1 Source in Organic Synthesis. Angew. Chem., Int. Ed. 2017, 56, 6384-6394. 
(4) For selected reviews, see: (a) Hamid, M. H. S. A.; Slatford, P. A.; Williams, J. M. J. Borrowing Hydrogen in the Activation of Alcohols. Adv. Synth. Catal. 2007, 349, 1555-1575. (b) Guillena, G.; Ramón, D. J.; Yus, M. Hydrogen Autotransfer in the N-Alkylation of Amines and Related Compounds using Alcohols and Amines as Electrophiles. Chem. Rev. 2010, 110, 1611-1641. (c) Huang, F.; Liu, Z.; Yu, Z. CAlkylation of Ketones and Related Compounds by Alcohols: Transition-Metal-Catalyzed Dehydrogenation. Angew. Chem., Int. Ed. 2016, 55, 862-875. (d) Corma, A.; Navas, J.; Sabater, M. J. Advances in One-Pot Synthesis through Borrowing Hydrogen Catalysis. Chem. Rev. 2018, 118, 1410-1459.

(5) (a) Trost, B. M. Atom Economy-A Challenge for Organic Synthesis: Homogeneous Catalysis Leads the Way. Angew. Chem., Int. Ed. Engl. 1995, 34, 259-281. (b) Trost, B. M. On Inventing Reactions for Atom Economy. Acc. Chem. Res. 2002, 35, 695-705.

(6) Watson, A. J. A.; Williams, J. M. J. The Give and Take of Alcohol Activation. Science 2010, 329, 635-636.

(7) (a) Qian, M.; Liauw, M. A.; Emig, G. Formaldehyde synthesis from methanol over silver catalysts. Appl. Catal., A 2003, 238, 211222. (b) Lin, W.-H.; Chang, H.-F. A study of ethanol dehydrogenation reaction in a palladium membrane reactor. Catal. Today 2004, 97, 181-188.

(8) (a) Grigg, R.; Mitchell, T. R. B.; Sutthivaiyakit, S.; Tongpenyai, $\mathrm{N}$. Oxidation of alcohols by transition metal complexes part V. Selective catalytic monoalkylation of arylacetonitriles by alcohols. Tetrahedron Lett. 1981, 22, 4107-4111. (b) Grigg, R.; Mitchell, T. R. B.; Sutthivaiyakit, S.; Tongpenyai, N. Transition metal-catalysed Nalkylation of amines by alcohols. J. Chem. Soc., Chem. Commun. 1981, 611-612.

(9) For selected Ru-catalyzed processes, see: (a) Arcelli, A.; BuiThe-Khai; Porzi, G. Selective conversion of primary amines into $\mathrm{N}, \mathrm{N}$ dimethylalkyl- or $N, N$-dialkylmethyl-amines with methanol and $\mathrm{RuCl}_{2}\left(\mathrm{Ph}_{3}\right)_{3}$. J. Organomet. Chem. 1982, 235, 93-96. (b) Li, Y.; Li, H.; Junge, H.; Beller, M. Selective ruthenium-catalyzed methylation of 2-arylethanols using methanol as $\mathrm{C} 1$ feedstock. Chem. Commun. 2014, 50, 14991-14994. (c) Dang, T. T.; Seayad, A. M. A Convenient Ruthenium-Catalysed $\alpha$-Methylation of Carbonyl Compounds using Methanol. Adv. Synth. Catal. 2016, 358, 3373-3380. For selected Ircatalyzed processes, see: (d) Ogawa, S.; Obora, Y. Iridium-catalyzed selective $\alpha$-methylation of ketones with methanol. Chem. Commun. 2014, 50, 2491-2493. (e) Shen, D.; Poole, D. L.; Shotton, C. C.; Kornahrens, A. F.; Healy, M. P.; Donohoe, T. J. Hydrogen-Borrowing and Interrupted-Hydrogen-Borrowing Reactions of Ketones and Methanol Catalyzed by Iridium. Angew. Chem., Int. Ed. 2015, 54, 1642-1645. (f) Chakrabarti, K.; Maji, M.; Panja, D.; Paul, B.; Shee, S.; Kanti Das, G.; Kundu, S. Utilization of $\mathrm{MeOH}$ as a $\mathrm{C} 1$ Building Block in Tandem Three-Component Coupling Reaction. Org. Lett. 2017, 19, 4750-4753. For a Rh-catalyzed process, see: (g) Chan, L. K. M.; Poole, D. L.; Shen, D.; Healy, M. P.; Donohoe, T. J. RhodiumCatalyzed Ketone Methylation Using Methanol Under Mild Conditions: Formation of $\alpha$-Branched Products. Angew. Chem., Int. $E d$. 2014, 53, 761-765. For $\mathrm{C}-\mathrm{H}$ functionalization of $\mathrm{MeOH}$, see: (h) Moran, J.; Preetz, A.; Mesch, R. A.; Krische, M. J. Iridiumcatalysed direct C-C coupling of methanol and allenes. Nat. Chem. 2011, 3, 287-290. (i) Nguyen, K. D.; Herkommer, D.; Krische, M. J. Enantioselective Formation of All-Carbon Quaternary Centers via C$\mathrm{H}$ Functionalization of Methanol: Iridium-Catalyzed Diene Hydrohydroxymethylation. J. Am. Chem. Soc. 2016, 138, 14210-14213. (j) Holmes, M.; Nguyen, K. D.; Schwartz, L. A.; Luong, T.; Krische, M. J. Enantioselective Formation of $\mathrm{CF}_{3}$-Bearing All-Carbon Quaternary Stereocenters via $\mathrm{C}-\mathrm{H}$ Functionalization of Methanol: Iridium Catalyzed Allene Hydrohydroxymethylation. J. Am. Chem. Soc. 2017, 139, 8114-8117.

(10) For selected reviews, see: (a) Quintard, A.; Rodriguez, J. A Step into an eco-Compatible Future: Iron- and Cobalt-catalyzed Borrowing Hydrogen Transformation. ChemSusChem 2016, 9, 28-30. (b) Zell, T.; Langer, R. From Ruthenium to Iron and Manganese-A Mechanistic View on Challenges and Design Principles of BaseMetal Hydrogenaton Catalysts. Chem CatChem 2018, 10, 1930-1940. (c) Filonenko, G. A.; van Putten, R.; Hensen, E. J. M.; Pidko, E. A. Catalytic (de)hydrogenation promoted by non-precious metals - Co, $\mathrm{Fe}$ and $\mathrm{Mn}$ : recent advances in an emerging field. Chem. Soc. Rev. 2018, 47, 1459-1483. (d) Kallmeier, F.; Kempe, R. Manganese Complexes for (De)Hydrogenation Catalysis: A Compatison to Cobalt and Iron Catalysts. Angew. Chem., Int. Ed. 2018, 57, 46-60.

(11) For selected Fe-catalyzed processes, see: (a) Quintard, A.; Constantieux, T.; Rodriguez, J. An Iron/Amine-Catalyzed Cascade Process for the Enantioselective Functionalization of Allylic Alcohols. Angew. Chem., Int. Ed. 2013, 52, 12883-12887. (b) Yan, T.; Feringa, B. L.; Barta, K. Iron catalysed direct alkylation of amines with alcohols. Nat. Commun. 2014, 5, 5602. (c) Rawlings, A. J.; Diorazio, L. J.; Wills, M. C-N Bond Formation between Alcohols and Amines Using an Iron Cyclopentadienone Catalyst. Org. Lett. 2015, 17, 1086-1089. (d) Elangovan, S.; Sortais, J.-B.; Beller, M.; Darcel, C. Iron-Catalyzed $\alpha$-Alkylation of Ketones with Alcohols. Angew. Chem., Int. Ed. 2015, 54, 14483-14486. (e) Mastalir, M.; Pittenauer, E.; Allmaier, G.; Kirchner, K. Manganese-Catalyzed Aminomethylation of Aromatic Compounds with Methanols as a Sustainable C1 Building Block. J. Am. Chem. Soc. 2017, 139, 8812-8815. (f) Vayer, M.; Morcillo, S. P.; Dupont, J.; Gandon, V.; Bour, C. Iron-Catalyzed Reductive Ethylation of Imines with Ethanol. Angew. Chem., Int. Ed. 2018, 57, 3228-3232. For selected Mn-catalyzed processes, see: (g) Elangovan, S.; Neumann, J.; Sortais, J.-B.; Junge, K.; Darcel, C.; Beller, M. Efficient and selective $\mathrm{N}$-alkylation of amines with alcohols catalyzed by manganese pincer complexes. Nat. Commun. 2016, 7, 12641. (h) Peña-López, M.; Piehl, P.; Elangovan, S.; Neumann, H.; Beller, M. Manganese-Catalyzed Hydrogen-Authotransfer C-C Bond Formation: $\alpha$-Alkylation of Ketones with Primary Alcohols. Angew. Chem., Int. Ed. 2016, 55, 14967-14971. For selected Co-catalyzed processes, see: (i) Rösler, S.; Ertl, M.; Irrgang, T.; Kempe, R. CobaltCatalyzed Alkylation of Aromatic Amines by Alcohols. Angew. Chem. Int. Ed. 2015, 54, 15046-15050. (j) Deibl, N.; Kempe, R. General and Mild Cobalt-Catalyzed C-Alkylation of Unactivated Amides and Esters with Alcohols. J. Am. Chem. Soc. 2016, 138, 10786-10789. (k) Yin, Z.; Zeng, H.; Wu, J.; Zheng, S.; Zhang, G. Cobalt-Catalyzed Synthesis of Aromatic, Aliphatic, and Cyclic Secondary Amines via a "Hydrogen-Borrowing" Strategy. ACS Catal. 2016, 6, 6546-6550.

(12) (a) ref 11g. (b) Neumann, J.; Elangovan, S.; Spannenberg, A.; Junge, K.; Beller, M. Improved and General Manganese-Catalyzed NMethylation of Aromatic Amines Using Methanol. Chem. - Eur. J. 2017, 23, 5410-5413. (c) Bruneau-Voisine, A.; Wang, D.; Dorcet, V.; Roisnel, T.; Darcel, C.; Sortais, J.-B. Mono- $N$-methylation of anilines with methanol catalyzed by a manganese pincer-complex. J. Catal. 2017, 347, 57-62.

(13) (a) Liu, Z.; Yang, Z.; Yu, X.; Zhang, H.; Yu, B.; Zhao, Y.; Liu, Z. Methylation of $\mathrm{C}\left(\mathrm{sp}^{3}\right)-\mathrm{H} / \mathrm{C}\left(\mathrm{sp}^{2}\right)-\mathrm{H}$ Bonds with Methanol Catalyzed by Cobalt System. Org. Lett. 2017, 19, 5228-5231. (b) Liu, Z.; Yang, Z.; Yu, X.; Zhang, H.; Yu, B.; Zhao, Y.; Liu, Z. Efficient CobaltCatalyzed Methylation of Amines Using Methanol. Adv. Synth. Catal. 2017, 359, 4278-4283.

(14) For selected general reviews on iron catalysis, see: (a) Bolm, C.; Legros, J.; Le Paih, J.; Zani, L. Iron-Catalyzed Reactions in Organic Synthesis. Chem. Rev. 2004, 104, 6217-6254. (b) Junge, K.; Schröder, K.; Beller, M. Homogeneous catalysis using iron complexes: recent developments in selective reductions. Chem. Commun. 2011, 47, 4849-4859. (c) Bauer, I.; Knölker, H.-J. Iron Catalysis in Organic Synthesis. Chem. Rev. 2015, 115, 3170-3387.

(15) See the Supporting Information for full experimental details.

(16) For an overview of the synthesis and reactivity of Knölker-type complexes, see: (a) Quintard, A.; Rodriguez, J. Iron Cyclopentadienone Complexes: Discovery, Properties, and Catalytic Reactivity. Angew. Chem., Int. Ed. 2014, 53, 4044-4055. For early applications in catalysis, see: (b) Casey, C. P.; Guan, H. An Efficient and Chemoselective Iron Catalyst for the Hydrogenation of Ketones. J. Am. Chem. Soc. 2007, 129, 5816-5817. (c) Casey, C. P.; Guan, H. Cyclopentadienone Iron Alcohol Complexes: Synthesis, Reactivity, and Implications for the Mechanism of Iron-Catalyzed Hydrogenation of Aldehydes. J. Am. Chem. Soc. 2009, 131, 2499-2507. (d) Casey, C. 
P.; Guan, H. Trimethylsilyl-Substituted Hydroxycyclopentadienyl Ruthenium Hydrides as Benchmarks To Probe Ligand and Metal Effects on the Reactivity of Shvo Type Complexes. Organometallics 2012, 31, 2631-2638.

(17) (a) Luh, T.-Y. Trimethylamine $\mathrm{N}$-oxide-a versatile reagent for organometallic chemistry. Coord. Chem. Rev. 1984, 60, 255-276. (b) Moyer, S. A.; Funk, T. Air-stable iron catalyse for the Oppenauertype oxidation of alcohols. Tetrahedron Lett. 2010, 51, 5430-5433. (c) Johnson, T. C.; Clarkson, G. J.; Wills, M. (Cyclopentadienone) iron Shvo Complexes: Synthesis and Applications to Hydrogen Transfer Reactions. Organometallics 2011, 30, 1859-1868. (d) Plank, T. N.; Drake, J. L.; Kim, D. K.; Funk, T. W. Air-Stable, Nitrile-Ligated (Cyclopentadienone)iron Dicarbonyl Compounds as Transfer Reduction and Oxidation Catalysts. Adv. Synth. Catal. 2012, 354, 597601.

(18) No background reaction occurs in the absence of [Fe] precatalyst under any of the reaction conditions employed in this study.

(19) (a) Nichols, J. M.; Bishop, L. M.; Bergman, R. G.; Ellman, J. A. Catalytic C-O Bond Cleavage of 2-Aryloxy-1-arylethanols and Its Application to the Depolymerization of Lignin-Related Polymers. J. Am. Chem. Soc. 2010, 132, 12554-12555. (b) Polidano, K.; ReedBerendt, B. G.; Basset, A.; Watson, A. J. A.; Williams, J. M. J.; Morrill, L. C. Exploring Tandem Ruthenium-Catalyzed Hydrogen Transfer and $\mathrm{S}_{\mathrm{N}} \mathrm{Ar}$ Chemistry. Org. Lett. 2017, 19, 6716-6719.

(20) For selected examples of the alkylation of indoles via borrowing hydrogen catalysis, see: (a) Whitney, S.; Grigg, R.; Derrick, A.; Keep, A. $\left[\mathrm{Cp} * \mathrm{IrCl}_{2}\right]_{2}$-Catalyzed Indirect Functionalization of Alcohols: Novel Strategies for the Synthesis of Substituted Indoles. Org. Lett. 2007, 9, 3299-3302. (b) Imm, S.; Bähn, S.; Tillack, A.; Mevius, K.; Neubert, L.; Beller, M. Selective ruthenium-catalyzed alkylation of indoles by using amines. Chem. - Eur. J. 2010, 16, 2705-2709.

(21) Skiles, G. L.; Yost, G. S. Mechanistic Studies on the Cytochrome P450-Catalyzed Dehydrogenation of 3-Methylindole. Chem. Res. Toxicol. 1996, 9, 291-297.

(22) For the methylation of oxindoles using Raney Nickel as a heterogeneous catalyst, see: (a) Wenkert, E.; Bringi, N. V. A New Procedure for Forming Carbon-Carbon Bonds. J. Am. Chem. Soc. 1958, 80, 5575-5576. (b) Wenkert, E.; Bringi, N. V.; Choulett, H. E. Raney Nickel-induced Alkylation Reactions. Acta Chem. Scand. 1982, 36b, 348-350. (c) Volk, B.; Mezei, T.; Simig, G. Raney NickelInduced 3-Alkylation of Oxindole with Alcohols and Diols. Synthesis 2002, 595-597.

(23) No conversion to the $N$-methylanilines is observed in the absence of $\mathrm{K}_{2} \mathrm{CO}_{3}$.

(24) (a) Thai, T.-T.; Mérel, D. S.; Poater, A.; Gaillard, S.; Renaud, J.-L. Highly active phosphine-free bifunctional iron complex for hydrogenation of bicarbonate reductive amination. Chem. - Eur. J. 2015, 21, 7066-7070. (b) Seck, C.; Diagne Mbaye, M.; Coufourier, S.; Lator, A.; Lohier, J.-F.; Poater, A.; Ward, T. R.; Gaillard, S.; Renaud, J.-L. Alkylation of Ketones Catalyzed by Bifunctional Iron Complexes: From Mechanistic Understanding to Application. ChemCatChem 2017, 9, 4410-4416.

(25) Diols such as 66 were not observed as byproducts in any of our ketone mono- or dimethylation experiments, presumably due to formaldehyde reacting preferentially with the conjugate base of the ketone starting material, as illustrated in Scheme 3C. 